\author{
Anna Dąbrowska \\ ORCID: 0000-0003-1406-5510 \\ Szkoła Główna Handlowa w Warszawie \\ adabro3@sgh.waw.pl
}

Mirosława Janoś-Kresło

ORCID: 0000-0002-3739-9620

Szkoła Główna Handlowa w Warszawie

mjanos@sgh.waw.pl

\title{
Suplementy diety a prawa konsumentów
}

Artykuł nadesłany: 13 kwietnia 2018 r.; artykuł zaakceptowany: 5 września 2018 r.

JEL Classification: I120, D1

Keywords: dietary supplements, consumer rights

\section{Abstract \\ Dietary supplements and consumer rights}

There are more and more food products on the market that are dietary supplements. It is a huge, growing and lucrative market. The primary purpose of diet supplements is to supplement a normal diet, possible shortages in diet, but this should be done under the supervision of a physician. Unfortunately, Poles rarely consult a doctor, preferring self-treatment. As it results from the inspections carried out, not all products are safe, have the correct composition and quality. In the article, considerations about dietary supplements were related to consumer rights. One of them is consumer education, which is the basis for making rational decisions and not being exposed to the undesirable effects of using, often excessively, dietary supplements. Subject literature and desk research were used for this purpose.

\section{Wprowadzenie}

Jednym z coraz mocniej zaznaczających się megatrendów konsumenckich jest dbałość o zdrowie. Dostrzegają to firmy oferujące zarówno produkty żywnościowe, jak i suplementy diety. Na te produkty bardzo żywo reagują konsumenci. Do podejmowania określonych decyzji zakupowych przekonują także coraz bardziej sugestywne reklamy. 
Wartość światowego rynku suplementów diety szacowana była w 2016 roku na 132,8 mld USD, a według prognoz w 2022 roku ma osiągnąć wartość 202,3 mld USD, co odpowiada wzrostowi CAGR ${ }^{1} \mathrm{w}$ wysokości $8,8 \%$. Pod względem geograficznym w 2016 roku największym rynkiem suplementów diety były kraje Azji i Pacyfiku, z udziałem 31\% w całkowitej wielkości tego rynku, i prognozuje się, że ta tendencja utrzyma się w najbliższych latach. Na kolejnych miejscach plasują się Ameryka Północna, z 28\% udziałem w rynku, i Europa, co do których przewiduje się umiarkowany wzrost konsumpcji suplementów diety. Zwraca się uwagę, że europejscy konsumenci wykazują wielkie zainteresowanie zdrowym stylem życia, który z kolei jest motorem konsumpcji zdrowej żywności².

Na rozwój rynku suplementów diety wpływają różne czynniki, w tym z jednej strony wzrost świadomości konsumentów na temat profilaktyki zdrowotnej oraz proces starzenia się społeczeństw, a z drugiej strony wzrost liczby oferowanych produktów poparty intensywnymi kampaniami reklamowymi. Natomiast czynnikami hamującymi mogą okazać się negatywna reklama i fałszywe oświadczenia dotyczące produktów, a także nieświadomość konsumentów w kwestii ich dawkowania. Suplementy diety są lukratywnym rynkiem, z wzrostem wartości sprzedaży prognozowanych w całej Europie.

W 27 krajach członkowskich Unii Europejskiej wartość tego rynku szacuje się na 7-8 mld euro rocznie, z coraz większym udziałem suplementów diety, zaklasyfikowanych przez Komisję Europejską do najbardziej niejednolitej grupy suplementów diety - mianowicie zawierających inne substancje o działaniu fizjologicznym. Należą tu między innymi karotenoidy, cieszące się coraz większą popularnością na światowym rynku suplementów diety. Zgodnie z raportem organizacji Global Industry Analysts, Inc. (GIA) z 2011 roku wartość światowego rynku karotenoidów w 2015 roku to 1,2 mld dolarów3 ${ }^{3}$.

Podstawowym celem stosowania suplementów diety jest uzupełnianie normalnej diety, ewentualnych niedoborów w diecie, jest to bowiem żywność i musi być stosowana rozważnie, a powinno to się odbywać pod kontrolą lekarza. Niestety Polacy rzadko konsultują się z lekarzem, preferując samoleczenie.

Jako że suplementy diety mogą zagrażać życiu i zdrowiu konsumentów, są przedmiotem zainteresowania i wystąpień przedstawicieli różnych instytucji i or-

${ }^{1}$ CAGR — skumulowany roczny wskaźnik wzrostu (ang. compound annual growth rate) jest to średni wskaźnik rocznego wzrostu w badanym okresie przy założeniu, że roczne wzrosty są dodawane do wartości bazy następnego okresu. W przybliżeniu można przyjąć, że CAGR to średnia wartość wskaźnika wzrostu z każdego roku.

2 Global Dietary Supplements Market will reach USD 220.3 Billion in 2022, http://zmrblog. com/2017/3854/dietary-supplements-market-worth-usd-220-3-billion-by-2022/ (dostęp: 4.01.2019); Dietary Supplements Market — Driven by Increasing demand for Health Products: Global Industry Analysis and Opportunity Assessment 2015-2025, https://www.futuremarketinsights.com/reports/ dietary-supplements-market (dostęp: 20.03.2018).

3 E. Pogorzelska, J. Hamułka, Analiza rynku suplementów diety z astaksantyna $w$ Polsce, „Handel Wewnętrzny” 2013, nr 4, s. 107-115. 
ganizacji, by wspomnieć Urząd Ochrony Konkurencji i Konsumentów, Narodowy Instytut Leków, Inspekcję Handlową, Państwową Inspekcję Sanitarną, Federację Konsumentów, ale także dociekań między innymi badaczy zajmujących się zachowaniami konsumentów, prawami konsumentów.

Warto przytoczyć wyniki kontroli Najwyższej Izby Kontroli przedstawione 10 lutego 2017 roku. Badania laboratoryjne suplementów diety zlecone przez NIK wykazały, że wiele suplementów nie ma cech deklarowanych przez producentów, a zdarzają się też po prostu szkodliwe dla zdrowia. W sprzedaży, w tym internetowej, ale także w sklepach stacjonarnych i aptekach, obok rzetelnych preparatów znajdowały się suplementy diety zafałszowane, zawierające na przykład bakterie chorobotwórcze, substancje zakazane z listy psychoaktywnych czy stymulanty podobne strukturalnie do amfetaminy, czyli działające jak narkotyki ${ }^{4}$.

W styczniu 2018 roku Inspekcja Handlowa podczas kontroli stwierdziła nieprawidłowości w co piątym suplemencie diety. Inspektorzy w czterech sklepach odkryli dziewięć partii przeterminowanych produktów. W szesnastu przypadkach producenci nie zawiadomili Głównego Inspektora Sanitarnego o nowych suplementach. Po kontroli przedsiębiorcy wycofali z rynku suplementy, które nie spełniały wymagań. Inspekcja wydała sześć decyzji o karach pieniężnych za niewłaściwe oznakowanie. Nałożyła też sześć mandatów karnych i wysłała pięćdziesiąt cztery zawiadomienia do organów nadzoru sanitarnego ${ }^{5}$.

$\mathrm{W}$ artykule rozważania o suplementach diety odniesiono do praw konsumentów. Jednym z nich jest edukacja konsumentów, która jest podstawą podejmowania racjonalnych decyzji i nienarażania się na niepożądane skutki stosowania, często nadmiernego, suplementów diety. $Z$ wypowiedzi lekarzy wynika, że po suplementy diety sięgają często osoby młode, które zażywają nawet do ponad dwudziestu różnych tabletek dziennie.

Takim zachowaniom sprzyjają reklamy, zachęcające do podawania suplementów diety nawet dzieciom. Z przekazu reklamowego wynika, że niepodanie dziecku suplementów świadczy o złej dbałości rodziców o dziecko.

\section{Charakterystyka rynku suplementów diety}

Zgodnie z prawem suplement diety nie jest lekiem, lecz środkiem spożywczym zawierającym składniki odżywcze, przeznaczonym do uzupełniania normalnej diety. Według art. 3 (39) ustawy z dnia 25 sierpnia 2006 roku o bezpieczeństwie żywności i żywienia

${ }^{4}$ NIK o dopuszczeniu do obrotu suplementów diety. Raport z dnia 10.02.2017, www.nik.gov. pl (dostęp: 17.08.2017).

5 Suplementy diety pod lupq. Kary i mandaty dla części producentów, https://tvn24bis.pl/z-kraju,74/inspekcja-handlowa-skontrolowala-suplementy-diety,807118.html (dostęp: 4.01.2019). 
to środek spożywczy, którego celem jest uzupełnienie normalnej diety, będący skoncentrowanym źródłem witamin lub składników mineralnych lub innych substancji wykazujących efekt odżywczy lub inny fizjologiczny, pojedynczych lub złożonych, wprowadzany do obrotu w formie umożliwiającej dawkowanie, w postaci: kapsułek, tabletek, drażetek i w innych podobnych postaciach, saszetek z proszkiem, ampułek z płynem, butelek z kroplomierzem i w innych podobnych postaciach płynów i proszków przeznaczonych do spożywania w małych, odmierzonych ilościach jednostkowych, $\mathrm{z}$ wyłączeniem produktów posiadających właściwości produktu leczniczego w rozumieniu przepisów prawa farmaceutycznego ${ }^{6}$.

Ustawa ta implementuje dyrektywę 2002/46/WE Parlamentu Europejskiego i Rady, której celem było ujednolicenie ustawodawstwa w zakresie suplementów żywnościowych we wszystkich państwach członkowskich Unii Europejskiej. Dyrektywę oceniono jako restrykcyjną, zbyt ograniczającą swobodę gospodarczą. W zakresie określania statusu produktu pozostała jednak pewna swoboda, co oznacza, że ten sam produkt może być wprowadzony na rynek jako suplement diety, a w innym kraju może być traktowany jako lek. Największymi europejskimi rynkami suplementów diety są: Niemcy, Francja, Włochy i Wielka Brytania. Kategorie, które cieszą się największym zainteresowaniem konsumentów, to: oleje rybne, probiotyki, ginko, echinacea i czosnek.

Według wyników badania Euromonitora z 2005 roku Polska w latach 19972005 była liderem pod względem dynamiki wzrostu liczby suplementów diety w Europie. Rynek suplementów diety wzrósł w tym okresie aż o 219\%. Wśród przyczyn tak wysokiej dynamiki można wyróżnić upowszechnienie suplementów diety oraz poszukiwanie przez producentów łatwej i szybkiej drogi wprowadzenia produktu na rynek zamiast skomplikowanej procedury rejestracyjnej leków ${ }^{7}$. Oznacza to, że suplementy diety dopuszczane są do obrotu bez konieczności przeprowadzania badań klinicznych potwierdzających bezpieczeństwo i skuteczność stosowania tych produktów.

Wzrost zainteresowania suplementami diety w Polsce skutkuje zwiększeniem ich sprzedaży. Dane za lata 2011-2020 przedstawia wykres 1 .

W 2015 roku Polacy wydali na suplementy diety 3,5 mld zł, kupując blisko 190 mln opakowań. Statystyczny Polak nabył więc sześć opakowań suplementów diety, wydając na nie około 100 zł. Szacowana wartość rynku na 2017 rok przekracza 4 mld złotych, co w praktyce oznacza sprzedaż ponad $200 \mathrm{mln}$ opakowań suplementów diety rocznie ${ }^{8}$. Do rejestru Głównego Inspektoratu Sanitarnego

${ }^{6}$ Dz.U. z 2006 r. Nr 171, poz. 1225 z późn. zm.

7 M. Kondrat, J. Stefańczyk-Kaczmarzyk, K. Gęsiak, Prawo suplementów diety, Warszawa 2012, s. 11-12.

8 M. Piotrowska, Już 72 proc. Polaków używa suplementów diety. Jednak nie wszystkie produkty sa bezpieczne, https://polskatimes.pl/juz-72-proc-polakow-uzywa-suplementow-diety-jednak-nie-wszystkie-produkty-sa-bezpieczne/ar/12434864 (dostęp: 10.02.2018). 


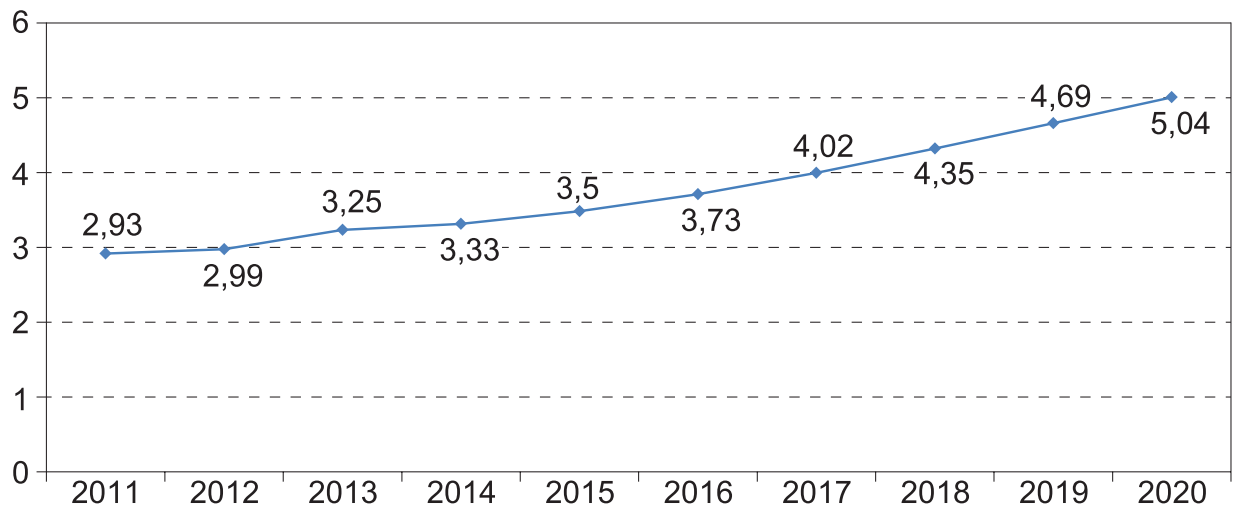

Wykres 1. Wartość sprzedaży suplementów diety w latach 2011-2020 (prognoza na lata 2016-2020)

Źródło: Raport Suplementy diety/Pacjent/Rynek/Trendy/Regulacje https://suplindex.com/wp-content/uploads/2017/10/RAPORT-Suplementy-diety-30.08.2017.pdf (dostęp: 10.02.2018).

od 2007 roku wpisano łącznie blisko 30 tys. produktów zgłoszonych jako suplementy diety. O ile w latach 2013-2015 przybywało ich 3-4 tys. rocznie, o tyle w 2016 roku już 7,4 tys. Badania wykazują, że rynek ten w latach 2017-2020 będzie rozwijał się w tempie około $8 \%$ rocznie 9 .

Jak podkreśla prezes Krajowej Rady Suplementów i Odżywek, suplementy diety to wciąż niedoceniana kategoria produktów. Najczęściej kupowanymi produktami są wyroby witaminowe i mineralne, na przykład z magnezem bądź witaminą D. Bardzo dobrze sprzedają się także wyroby stymulujące odporność, probiotyki oraz kwasy omega-3 ${ }^{10}$.

Polscy konsumenci spożywają coraz więcej suplementów diety, traktując je nierzadko jako panaceum na różne dolegliwości. Nie wiadomo jednak dokładnie, co spożywamy, gdyż wprowadzanie do obrotu i sprzedaż są w praktyce poza skuteczną kontrolą.

Jak zauważa NIK, w obecnym stanie prawnym każdy może wprowadzić suplement na rynek, deklarując jedynie jego skład organom sanitarnym, dokonując tak zwanej notyfikacji. Teoretycznie produkt, który trafia na rynek, został zbadany, jednak w praktyce skala rynku przekracza możliwości kontrolne Inspekcji Sanitarnej. Kontrole, które prowadzi Inspekcja, dotyczą zaledwie części rynku, a same postępowania nierzadko mogą trwać — jak wykazała kontrola NIK nawet kilka lat. W licznych przypadkach sprzedawane suplementy diety nie są badane. Ochrona konsumentów staje się wówczas fikcją. Dane uzyskane podczas

9 Rynek suplementów diety do 2021 rokubędzie rósło 7 proc. rocznie. Obecniejest wart 3,5 mldzl, https://biznes.newseria.pl/news/rynek-suplementow-diety,p609045232 (dostęp: 10.02.2018).

10 Rynek suplementów diety obecnie jest wart 3,5 mld zt, http://www.wirtualnemedia.pl/artykul/rynek-suplementow-diety-obecnie-jest-wart-3-5-mld-zl\# (dostęp: 10.02.2018). 
kontroli wskazują, że na tle rozmiarów podaży i spożycia możliwość prawdziwie skutecznej kontroli rynku suplementów przez organy Inspekcji Sanitarnej po prostu nie istnieje.

Z wybranych do kontroli czterdziestu pięciu suplementów diety, które nie powinny być wprowadzone do obrotu ze względu na zawartość niedozwolonych składników, aż trzydzieści osiem w czasie prowadzenia badań kontrolnych przez NIK znajdowało się w sprzedaży (sprawdzono sprzedaż internetową). Produkty te zawierały składniki zakwestionowane przez Głównego Inspektora Sanitarnego, stwarzające niebezpieczeństwo dla konsumentów, gdyż - jak wskazywał Inspektor w pismach kierowanych do podmiotów wprowadzających te produkty do obrotu - mogły między innymi wykazywać właściwości alergenne i rakotwórcze, powodować zakażenia dróg oddechowych i moczowych, zapalenie opon mózgowo-rdzeniowych, a także przyczyniać się do powstawania ropni, zapalenia wsierdzia, osierdzia, czasami zatruć pokarmowych.

Jak podaje NIK 3 lutego 2017 roku, z kwestionowanych trzydziestu ośmiu suplementów diety nadal trzydzieści trzy zawierające szkodliwe substancje znajdowały się w sprzedaży internetowej ${ }^{11}$.

W ostatnich latach obserwuje się rozwój trendu konsumenckiego zwanego wellness, czyli zapewnienie stanu zdrowej równowagi umysłu, ciała i ducha człowieka $^{12}$. Dzięki niemu coraz więcej konsumentów zwraca uwagę na swój styl życia, chcąc polepszyć w ten sposób stan zdrowia, dostosowując go do wymogów dobrego zdrowia. Konsumenci modyfikują nawyki żywieniowe, korzystają z różnych form aktywności fizycznej jako sposobu spędzania wolnego czasu. Trend zdrowego stylu życia skutkował wzrostem zapotrzebowania na preparaty bogate w składniki mineralne i witaminy, których celem jest uzupełnienie niedoborów w codziennej diecie. Zmiana świadomości kupujących przyczyniła się do stałej obecności preparatów uzupełniających w codziennym żywieniu człowieka. Jednakże trend wellness może mieć także niekorzystne skutki dla konsumentów. Pierwszym z nich jest samoleczenie, które charakteryzuje się skłonnością do diagnozowania siebie i innych oraz przeprowadzania kuracji leczniczej bez wcześniejszej konsultacji z lekarzem lub farmaceutą. Według raportu z badań sondażowych koncernu farmaceutycznego Bayer ${ }^{13}$ z 2016 roku aż 95\% osób od czasu do czasu leczy się samemu. Do najczęstszych dolegliwości, które Polacy leczą

11 S. Szadkowski, Szokujący raport NIK: Suplementy diety sa praktycznie poza kontrola, http://wgospodarce.pl/informacje/33445-szokujacy-raport-nik-suplementy-diety-sa-praktycznie-poza-kontrola-a-czesc-z-nich-moze-zawierac-narkotyki-i-drobnoustroje (dostęp: 10.03.2018).

12 A. Dąbrowska, Trendy konsumpcji i zachowań polskich konsumentów, [w:] Konsumpcja a rozwój społeczno-gospodarczy regionów w Polsce, red. A. Kusińska, Warszawa 2011, s. 173-199; A. Dąbrowska, I. Ozimek, Zdrowy styl życia jako nowy trend w zachowaniach współczesnych konsumentów, „Handel Wewnętrzny” 2011, nr 4, s. 50-59; B. Mróz, Konsument w globalnej gospodarce. Trzy perspektywy, Warszawa 2013, s. 138 n.

13 Odpowiedzialne (samo)leczenie, https://www.bayer.com.pl/pl/media/odpowiedzialne-samoleczenie.php (dostęp: 4.01.2019). 
bez konsultacji lekarskich, należą kolejno: przeziębienie (69\%), gorączka (68\%), problemy układu pokarmowego (56\%), dolegliwości bólowe (47\%). Raport pokazuje również, że 70\% osób łączy stan psychiczny ze zdrowiem fizycznym. Sondaż był jednocześnie elementem kampanii uświadamiającej konsumentów o pozytywnych i negatywnych stronach przyjmowania preparatów leczniczych bez skonsultowania się z lekarzem. Wyniki te potwierdza raport Polacy a suplementy diety Agencji Badań Rynku i Opinii SW Research z 2017 roku ${ }^{14}$. Większość Polaków przyjmuje suplementy diety, ale tylko $17 \%$ decyzję o włączeniu ich w dietę konsultuje z lekarzem lub farmaceutą. Ponad połowa badanych decyzję o zakupie i przyjmowaniu tego typu preparatów podejmuje samodzielnie.

Drugim zauważalnym efektem trendu wellness jest spożywanie suplementów diety. Konsumenci wierzą, że dzięki nim poprawią swoje samopoczucie lub wyleczą się z chorób, a suplementy często sobie aplikują sami.

Można powiedzieć, że wśród polskich konsumentów obserwuje się nową modę, która dotyczy kupowania i spożywania preparatów uzupełniających. Aż $72 \%$ Polaków przyznaje się do zażywania suplementów diety, a prawie połowa badanych przez Agencję Badań Rynku i Opinii SW Research regularnie stosuje suplementy diety i deklaruje, że odczuwa wyraźną poprawę stanu zdrowia. Konsumenci często nie są świadomi, że suplementy to jedynie środki spożywcze, więc nie mają właściwości leczniczych. Nieprawidłowej ocenie preparatów sprzyja też, że najczęściej kupuje się je w aptekach (65\% badanych), w których mają status równy z lekami wydawanymi na receptę. $\mathrm{W}$ tym przypadku punkt sprzedaży sprawia, że konsumenci postrzegają suplementy jako produkty bezpieczne dla zdrowia i przebadane klinicznie. W internecie suplementy diety kupuje co dziesiąty badany, w sklepach specjalistycznych, supermarketach — ponad $6 \%$, sklepach zielarskich niespełna $5 \%$, sklepach spożywczych $3,7 \%$ i na bazarach $2 \%{ }^{15}$. Niewątpliwie dużo prościej pójść do apteki po tani suplement diety, niż stać w kolejce do lekarza (szczególnie w okresach nasileń zachorowań na grypę, przeziębienie), robić nieprzyjemne i niekiedy kosztowne badania i wykupywać drogie leki.

M. Mieszkowska i E. Michota-Katulska przedstawiają negatywny wpływ suplementów diety na ludzki organizm. Istniejące zagrożenia mogą wynikać z: przedawkowania tych preparatów, stosowania ich w niewystarczających ilościach, interakcji między lekami a składnikami odżywczymi, wpływu na wyniki badań diagnostycznych, przeciwwskazań przy niektórych chorobach ${ }^{16}$.

Z badania CBOS wynika, że większość dorosłych (71\%) jest świadoma, że leki i preparaty farmaceutyczne dostępne bez recepty mogą mieć negatywny

${ }^{14} 65$ proc. Polaków suplementy diety kupuje w aptekach, Polacy a suplementy diety. Raport badawczy, 6.03.2017, http://swresearch.pl/raporty/czytaj/id/64/65-proc-polak-w-suplementy-diety-kupuje-w-aptekach (dostęp: 10.03.2018).

15 Ibidem.

16 Więcej E. Mieszkowska, M. Michota-Kotulska, Suplementy diety - korzyści i działania niepożądane, „Bezpieczeństwo Pracy” 2008, nr 6, http://archiwum.ciop.pl/28258 (dostęp: 4.02.2018). 
wpływ na zdrowie. Więcej niż co piąty ankietowany (22\%) nie podziela takich obaw. Ponad jedna czwarta badanych (28\%) twierdzi, że zdarzyło im się stosować leki dostępne bez recepty w niewłaściwy sposób — niezgodnie z zaleceniami, na przykład zwiększając dawkę, używając ich dłużej niż wskazane (20\%), lekceważąc skutki uboczne (9\%) lub przeciwwskazania, które ich dotyczą (8\%) - a także przyjmować leki z przyzwyczajenia, choć nie jest to konieczne (7\%), oraz wbrew negatywnej opinii lekarza o takim sposobie leczenia $(4 \%)^{17}$.

Polacy niewiele wiedzą o suplementach diety. Przeprowadzone przez TNS Polska w 2014 roku badanie pt. Świadome samoleczenie w Polsce - www.lekiczysuplementy.pl 2014 wykazało, że wiele osób mylnie uznało suplementy za „witaminy” (31\%) czy „minerały” (8\%), aż 41\% zaś badanych przypisało suplementom diety właściwości lecznicze, których produkty te nie mają. Ponadto $50 \%$ pytanych uważało, że suplementy są tak samo kontrolowane jak leki, 38\% było przekonanych o bezpieczeństwie samowolnego przyjmowania suplementów, bez konsultacji z lekarzem, a zdaniem $25 \%$ suplementów nie da się przedawkować18.

\section{Prawa konsumenta}

Konsumenci świadomi swojej pozycji na rynku wiedzą, że mają swoje prawa i że powinny być one przestrzegane. Widać to zwłaszcza w dniu 15 marca, czyli Światowym Dniu Praw Konsumenta.

Prezydent USA J.F. Kennedy 15 marca 1962 roku w wystąpieniu przed Kongresem odniósł się do ochrony praw konsumenckich. Stwierdził, że

konsumenci są jedyną grupą ekonomiczną, która nie jest skutecznie zorganizowana i której punkt widzenia jest najczęściej ignorowany. [...] Jeśli się oferuje konsumentom artykuły złej jakości, jeśli ceny są wygórowane, jeśli produkty są niebezpieczne lub bezwartościowe, jeśli konsument nie jest w stanie dokonać wyboru na podstawie posiadanych informacji, to jego pieniądz przestaje mieć wartość, jego zdrowie i bezpieczeństwo znajdują się w stanie zagrożenia, a interes narodowy na tym cierpi ${ }^{19}$.

Według art. 22 (1) kodeksu cywilnego za konsumenta uważa się osobę fizyczną dokonującą z przedsiębiorcą czynności prawnej niezwiązanej bezpośrednio z jej działalnością gospodarczą lub zawodową.

Wśród praw przysługujących konsumentom najczęściej wymienia się:

1. Prawo do ochrony zdrowia i bezpieczeństwa - człowiek, chcąc zaspokoić swoje potrzeby, musi konsumować towary i usługi nabywane na rynku. Oferenci

17 CBOS, Leki dostepne bez recepty i suplementy diety. Komunikat z badań nr 158/2016, Warszawa, listopad 2016.

18 PAP, Wielki problem z suplementami diety: Polacy nie wiele o nich wiedza, a producenci to wykorzystuja, http://wgospodarce.pl/informacje/11770-wielki-problem-z-suplementami-diety-polacy-nie-wiele-o-nich-wiedza-a-producenci-to-wykorzystuja (dostęp: 17.02.2018).

19 A. Dąbrowska, M. Janoś-Kresło, I. Ozimek, Ochrona i edukacja konsumenta w gospodarce rynkowej, Warszawa 2005, s. 22. 
produktów mają obowiązek precyzowania cech ich bezpieczeństwa oraz właściwego informowania konsumentów o możliwości wystąpienia zagrożeń. Akty prawne szczegółowo określają zasady rejestracji leków. Zgodnie z Prawem farmaceutycznym decyzja dotycząca rejestracji produktów leczniczych w Polsce należy do Ministra Zdrowia, który od Urzędu Rejestracji Produktów Leczniczych, Wyrobów Medycznych i Produktów Biobójczych otrzymuje szczegółowy raport $\mathrm{z}$ oceny leku wraz z rekomendacją. Na podstawie przygotowanej dokumentacji wydaje decyzję. Proces ten nie powinien przekraczać 210 dni, ale w praktyce w Polsce trwa często dwa-trzy lata, a nawet dłużej20.

2. Prawo do ochrony interesów ekonomicznych — zdarza się, że przedsiębiorcy z racji swojej pozycji rynkowej mogą narzucać niekorzystne warunki umowy, uprawiać nieuczciwą konkurencję, stosować nadmiernie wysokie ceny czy nierzetelne praktyki marketingowe i handlowe. Działania marketingowe na rynku farmaceutycznym są istotnym elementem funkcjonowania całego sektora. W wypadku suplementów diety droga przekazu marketingowego nie obejmuje lekarza, chociaż niektóre firmy kierują suplementy diety również do przedstawicieli zawodu medycznego. Nie zmienia to faktu, że to media głównie napędzają tę machinę. I właśnie w tę formę przekazu marketingowego najwięcej inwestują producenci suplementów diety. Problemem jest też niewłaściwe oznakowanie, prezentowanie suplementów diety. Przede wszystkim powinna znaleźć się informacja, że produkt jest „suplement diety”. Dozwolone jest użycie nazwy handlowej jako dodatkowego oznaczenia ${ }^{21}$. Tymczasem w większości wypadków to właśnie nazwa handlowa gra główną rolę, a informacja „suplement diety” schodzi na drugi plan. Niczego nieświadomy konsument jest wprowadzany w błąd.

3. Prawo do informacji i edukacji — rzetelna, pełna informacja pozwala konsumentom na dokonywanie przemyślanych wyborów zgodnie z indywidualnymi potrzebami i preferencjami. Konsumenci potrzebują rzetelnej informacji o cechach oferowanych produktów, warunkach bezpiecznego ich używania (korzystania), a także procedurach reklamacyjnych. W akcji informacyjnej na rzecz konsumentów na temat suplementów diety udział wzięło aż dwanaście instytucji: Główny Inspektorat Farmaceutyczny, Główny Inspektorat Sanitarny, Ministerstwo Finansów, Ministerstwo Zdrowia, Instytut Żywności i Żywienia, Narodowy Instytut Leków, Narodowy Instytut Zdrowia Publicznego — Państwowy Zakład Higieny, Rada Reklamy, Urząd Ochrony Konkurencji i Konsumentów, Urząd Rejestracji Produktów Leczniczych, Wyrobów Medycznych i Produktów Biobójczych, Federacja Konsumentów oraz Stowarzyszenie Konsumentów Polskich. W ramach tej akcji, w październiku 2015 roku, wysłano listy do 315 producentów i dystrybutorów suplementów diety. Celem było zwrócenie uwagi na treści reklam zamieszczanych przez te podmioty, które nie zawsze są rzetelne i mogą wprowadzać w błąd konsu-

${ }^{20}$ H. Mruk, B. Pilarczyk, M. Michalik, Marketing strategiczny na rynku farmaceutycznym, Warszawa 2014, s. 33.

21 Ibidem. 
mentów ${ }^{22}$. Akcja miała też służyć zwiększeniu ochrony i świadomości konsumentów. Z kolei w listopadzie 2015 roku stworzony został specjalny poradnik konsumencki pt. Co warto wiedzieć o suplementach diety. Z raportu Krajowej Rady Radiofonii i Telewizji wynika, że od 1997 do 2015 roku liczba reklam produktów farmaceutycznych (w tym suplementów diety) wzrosła prawie dwudziestokrotnie, przy tylko trzykrotnym wzroście ogólnej liczby reklam. W 1997 roku przekazy reklamowe produktów farmaceutycznych obejmowały tylko 4,6\% wszystkich reklam, a w roku 2015 produkty farmaceutyczne pojawiały się już w co czwartym przekazie reklamowym i było to $24,7 \%$ ogółu reklam ${ }^{23}$. Reklama produktów leczniczych regulowana jest ustawą Prawo farmaceutyczne ${ }^{24}$ oraz rozporządzeniem Ministra Zdrowia z dnia 21 listopada 2008 roku dotyczącym reklamy produktu leczniczego ${ }^{25}$ i podlega wielu określonym $w$ tych aktach ograniczeniom ${ }^{26}$.

Produkt leczniczy nie może być prezentowany przez osoby znane publicznie, naukowców, osoby z wykształceniem medycznym lub farmaceutycznym lub sugerujące zdobycie takiego wykształcenia ${ }^{27}$. Jest to nagminnie stosowane w reklamach suplementów diety, które nie są tak szczegółowo regulowane prawnie. Artykuł 46 ustawy o bezpieczeństwie żywności i żywienia wprowadza dwie generalne reguły. Po pierwsze, reklama suplementu diety nie może wprowadzać w błąd (na przykład w zakresie składu lub właściwości produktu). Po drugie, reklama nie może przypisywać suplementowi diety właściwości zapobiegania chorobom lub ich leczenia ani odwoływać się do takich właściwości. Ze względu na niewystarczającą wiedzę konsumenci często mylą suplementy diety z lekami i darzą te produkty dużym zaufaniem. Zważywszy na nieświadomość konsumentów i nadużywanie przez nich tych produktów, interwencja ze strony państwa jest konieczna, ponieważ taki stan rzeczy znacznie zagraża zdrowiu i życiu konsumentów.

4. Prawo do efektywnego dochodzenia roszczeń - oznacza stworzenie konsumentom mechanizmów prawnych i pocedur ułatwiających w sposób tani oraz szybki dochodzenia roszczeń, a także pomoc w egzekwowaniu praw konsumentów.

5. Prawo do reprezentacji - oznacza zapewnienie konsumentom warunków do zrzeszania się, prezentowania stanowiska konsumentów i zbiorowej ochrony roszczeń. Instytucje rządowe (Urząd Ochrony Konkurencji i Konsumentów, Inspekcja Handlowa, Europejskie Centrum Konsumenckie, Rzecznik Praw Obywatelskich), samorządowe (miejski/powiatowy rzecznik konsumentów) i organizacje konsumenckie (Federacja Konsumentów, Stowarzyszenie Konsumentów Polskich) służą konsumentowi pomocą, doradztwem i mogą go reprezentować

22 Ibidem.

23 NIK o dopuszczeniu do obrotu suplementów diety.

24 Dz.U. z 2008 r. Nr 45, poz. 271 z późn. zm., nowelizacja 7 kwietnia 2017 r.

25 Dz.U. Nr 210, poz. 1327.

${ }^{26}$ Główny Inspektorat Farmaceutyczny, Reklama produktów leczniczych, www.gif.gov.pl (dostęp: 12.09.2017).

27 Ibidem. 
w sądach polubownych i powszechnych. Aby jednak konsumenci mogli korzystać z pomocy tych instytucji i organizacji, muszą wiedzieć o ich istnieniu i prowadzonej przez nich działalności.

\section{Przejawy naruszenia praw konsumentów na rynku suplementów diety}

W ostatnich latach na polskim rynku farmaceutycznym pojawiła się ogromna ilość suplementów diety. Ich dostępność bez recepty, a także wszechobecna promocja spowodowały duże zainteresowanie ze strony konsumentów, co przełożyło się na wzrost sprzedaży tej kategorii produktów.

Najwyższa Izba Kontroli w opublikowanym w lutym 2017 roku raporcie z kontroli suplementów diety wykazała występowanie w niektórych suplementach diety szkodliwych dla zdrowia i życia substancji. Stwierdzono, że rynek suplementów diety wymaga niezwłocznej poprawy regulacji prawnych dotyczących wprowadzania tych produktów na rynek. Trudno odpowiedzieć na pytanie, co tak naprawdę znajduje się w suplementach diety, ponieważ w obowiązującym stanie prawnym każdy producent może wprowadzić suplement na rynek, deklarując jedynie, że jego skład jest zgodny z wytycznymi Głównego Inspektoratu Sanitarnego. Tym samym każdy produkt może być przebadany, ale wielkość tego rynku powoduje, że kontroli podlega zaledwie niewielka ich część.

Problem ten dostrzegł także Urząd Ochrony Konkurencji i Konsumentów. W poradniku pt. Suplementy diety daje kilka dobrych rad.

1. Nie powinno się stosować suplementów diety bez dostatecznej wiedzy. Ich przyjmowanie musi być skonsultowane z lekarzem, farmaceutą lub dietetykiem oraz poprzedzone właściwymi badaniami, gdyż każdy organizm jest inny. Tylko wówczas będzie możliwa właściwa i skuteczna suplementacja (uzupełnianie niedoborów).

2. Diagnoza własnego stanu zdrowia (czy też dziecka) na podstawie reklam nie jest miarodajna. Te same objawy (między innymi przemęczenie, apatia, brak apetytu) mogą mieć różne przyczyny, niekoniecznie związane z niedoborem magnezu, witamin lub innej substancji sugerowanej przez reklamę.

3. Reklamy często odwołują się do stylu życia lub wieku, uzasadniając „konieczność" suplementacji. Aktywność fizyczna lub przynależność do określonej grupy wiekowej (na przykład 60+) nie oznacza niedoboru konkretnej substancji odżywczej.

4. Suplementami diety nie można zastąpić posiłku lub właściwego, zrównoważonego sposobu odżywiania. Suplement diety nie jest też alternatywą aktywności fizycznej czy zdrowego stylu życia.

5. Należy ostrożnie podchodzić do informacji prezentowanych w reklamach oraz na stronach producentów, suplementy diety są środkiem spożywczym. Także 
blogi i fora internetowe często zawierają treści zamieszczane przez użytkowników udających zadowolonych klientów, a w rzeczywistości opłacanych przez producentów czy dystrybutorów suplementów diety. $Z$ dystansem trzeba traktować artykuły w prasie lub programy telewizyjne. Niektóre $\mathrm{z}$ nich są sponsorowane przez producentów i nie zawsze, choć powinna, informacja o tym jest wyraźnie podawana ${ }^{28}$.

Budowanie świadomości konsumenckiej wymaga pozyskiwania sprawdzonych informacji i ich konfrontowania. Służyć temu mogą publikowane przez instytucje rządowe, takie jak UOKiK, i organizacje konsumenckie poradniki. A zapoznanie się z ich treścią może nas uchronić przed naruszeniem praw konsumentów przez firmy na przykład oferujące suplementy diety. Gwoli przykładu — firma Aflofarm Farmacja Polska, producent preparatów RenoPuren Zatoki Hot i RenoPuren Zatoki Junior, musi zapłacić prawie $26 \mathrm{mln}$ zł kary za wprowadzanie konsumentów w błąd - postanowił Urząd Ochrony Konkurencji i Konsumentów. Karę nałożono w związku z reklamami preparatów, które zdaniem UOKiK prezentowały suplementy diety tak, aby sprawiały wrażenie, że mają właściwości lecznicze. Tymczasem suplementy nie są lekami. W swojej decyzji nr DDK-5/2017 UOKiK stwierdził, że firma zastosowała praktyki naruszające zbiorowe interesy konsumentów. Aflofarm Farmacja Polska złożyła odwołanie od tej decyzji.

UOKiK nałożył także karę niefinansową za reklamy Magmisiów. Reklamy suplementu diety Magmisie sugerowały, że powszechnym powodem kłopotów dzieci z koncentracją jest niedobór magnezu i że zaradzi temu podanie żelków. Tymczasem przyczyny tych problemów mogą być różne, podobnie jak sposoby ich rozwiązania, na przykład zmiana diety lub trybu życia, wizyta u lekarza. UOKiK uznał, że taki przekaz mógł wprowadzać konsumentów w błąd. Jak czytamy w decyzji nr 10/2017, Aflofarm Farmacja Polska wyraziła zgodę na wyemitowanie komunikatu, w którym oświadcza (w ogólnym zarysie), że reklamy suplementów diety Magmisie emitowane od 2 kwietnia 2016 do 1 marca 2017 roku mogły wprowadzać konsumentów w błąd.

Zważywszy na te przykłady, należy zdecydowanie podkreślić, że reklama i prezentacja środków spożywczych nie może:

— wprowadzać w błąd konsumenta, przypisując środkom spożywczym właściwości lecznicze lub odwołując się do takich właściwości, a także co do charakterystyki środka spożywczego, w tym jego nazwy, składu, ilości, trwałości, źródła czy metod wytwarzania;

— zawierać oświadczeń żywieniowych lub zdrowotnych niezgodnych z przepisami rozporządzenia (WE) nr 1924/2006 Parlamentu Europejskiego i Rady $\mathrm{z}$ dnia 20 grudnia 2006 roku;

28 UOKiK, Co warto wiedzieć o suplementach diety?, https://uokik.gov.pl/download.php? plik=17285 (dostęp: 12.02.2018). 
— sugerować konsumentom, przez zamieszczanie informacji, że zróżnicowana czy zbilansowana dieta nie dostarczy do organizmu wystarczającej ilości składników odżywczych.

\section{Podsumowanie}

Polska dołączyła do krajów, w których obserwuje się relatywnie wysoką konsumpcję leków dostępnych bez recepty, w tym suplementów diety. W Polsce wydaje się najwięcej na promocję tych środków, co sprawia, że jesteśmy jedynym krajem w Europie, w którym rynek reklamowy produktów farmaceutycznych przewyższa wartością inne rynki ${ }^{29}$.

Krytyczne podejście do suplementów diety bierze się między innymi z tego, że reklamy tych produktów żywnościowych są bardzo sugestywne. Są pośrednio coraz częściej kierowane do dzieci. Rodziców przekonuje się, że muszą swojemu dziecku w pierwszej klasie, które ma depresję z powodu nauki, podawać suplement zawierający magnez. Jest to budowanie u matki poczucia winy, że niekupienie reklamowanego produktu jest jednoznaczne z niedbaniem o odporność swojego dziecka. Przykładów takich reklam jest coraz więcej.

Najwyższa Izba Kontroli uznaje za zasadne zwrócenie się do Prezesa Rady Ministrów o podjęcie przez rząd inicjatywy ustawodawczej mającej między innymi na celu:

1. wprowadzenie systemu opłat za notyfikację suplementów diety;

2. wprowadzenie systemu ostrzegania konsumentów przed niezbadanymi suplementami diety znajdującymi się w obrocie przez informowanie o fakcie nienotyfikowania danego suplementu diety;

3. wydzielenie z rejestru GIS suplementów diety, wobec których podjęto działania weryfikujące ze względu na wątpliwości co do ich jakości (szczególnie bezpieczeństwa);

4. uregulowanie procedur wycofywania z rynku przez producenta lub dystrybutora suplementów diety bądź zaprzestania ich produkcji/dystrybucji i rezygnacji z wprowadzania do obrotu;

5. ustalenie zerowego poziomu wybranych składników suplementów diety, gdy takie składniki, ze względu na ochronę życia lub zdrowia ludzkiego, uznane zostaną za niebezpieczne;

6. zwiększenie kar pieniężnych dla podmiotów wprowadzających do obrotu niebezpieczne lub nielegalne suplementy diety, tak by, zgodnie $\mathrm{z}$ art. 17 ust. 2 unijnego rozporządzenia nr 178/2002, były skuteczne, proporcjonalne i odstraszające.

29 W. Zajdel, Wszechobecna reklama leków OTC oraz suplementów diety, http://www.rynek aptek.pl/wywiad/wszechobecna-reklama-lekow-otc-oraz-suplementow-diety,13082.html (dostęp: 4.02.2018). 
Jak słusznie zauważa prezes Fundacji EISD Katarzyna Wójcicka, żadne regulacje ani kontrole nie będą tak skuteczne jak ostrożność konsumenta. Ostrożność w wyborze produktu na rynku i korzystanie z pewnych źródeł informacji.

Zgodzić się należy z opinią ${ }^{30}$, że ważnym i istotnym zadaniem ustawodawcy jest właściwe wprowadzanie konsumenckich regulacji ochronnych, które obejmują swoim zakresem czynności życia społecznego, tak istotne z punktu widzenia jednostek społecznych. Ochrona konsumenta odgrywa szczególną rolę w tych dziedzinach, w których wiedza i świadomość społeczeństwa są znikome lub niewielkie.

\section{Bibliografia}

65 proc. Polaków suplementy diety kupuje w aptekach, Polacy a suplementy diety. Raport badawczy, 6.03.2017, http://swresearch.pl/raporty/czytaj/id/64/65-proc-polak-w-suplementy-diety-kupuje-w-aptekach (dostęp: 10.03.2018).

CBOS, Leki dostępne bez recepty i suplementy diety. Komunikat z badań nr 158/2016, Warszawa, listopad 2016.

Dąbrowska A., Trendy konsumpcji i zachowań polskich konsumentów, [w:] Konsumpcja a rozwój społeczno-gospodarczy regionów w Polsce, red. A. Kusińska, Warszawa 2011.

Dąbrowska A., Janoś-Kresło M., Ozimek I., Ochrona i edukacja konsumenta w gospodarce rynkowej, Warszawa 2005.

Dąbrowska A., Ozimek I., Zdrowy styl życia jako nowy trend w zachowaniach współczesnych konsumentów, „Handel Wewnętrzny” 2011, nr 4.

Dietary Supplements Market - Driven by Increasing demand for Health Products: Global Industry Analysis and Opportunity Assessment 2015-2025, https://www.futuremarketinsights.com/reports/dietary-supplements-market (dostęp: 20.03.2018).

Global Dietary Supplements Market will reach USD 220.3 Billion in 2022, Zion Market Research, http://zmrblog.com/2017/3854/dietary-supplements-market-worth-usd-220-3-billion-by-2022/ (dostęp: 4.01.2019).

Główny Inspektorat Farmaceutyczny, Reklama produktów leczniczych, www.gif.gov.pl (dostęp: 12.09.2017).

Kondrat M., Stefańczyk-Kaczmarzyk J., Gęsiak K., Prawo suplementów diety, Warszawa 2012.

Mieszkowska E., Michota-Kotulska M., Suplementy diety - korzyści i działania niepożądane, „Bezpieczeństwo Pracy” 2008, nr 6, http://archiwum.ciop.pl/28258 (dostęp: 4.02.2018).

Mróz B., Konsument w globalnej gospodarce. Trzy perspektywy, Warszawa 2013.

Mruk H., Pilarczyk B., Michalik M., Marketing strategiczny na rynku farmaceutycznym, Warszawa 2014.

NIK o dopuszczeniu do obrotu suplementów diety. Raport z dnia 10.02.2017, https://www.nik.gov. $\mathrm{pl} /$ aktualnosci/nik-o-dopuszczaniu-do-obrotu-suplementow-diety.html (dostęp: 17.03.2018).

Odpowiedzialne (samo)leczenie, https://www.bayer.com.pl/pl/media/odpowiedzialne-samoleczenie.php (dostęp: 4.01.2019).

PAP, Wielki problem z suplementami diety: Polacy nie wiele o nich wiedza, a producenci to wykorzystuja, http://wgospodarce.pl/informacje/11770-wielki-problem-z-suplementami-diety-polacy-nie-wiele-o-nich-wiedza-a-producenci-to-wykorzystuja (dostęp: 17.02.2018).

30 M. Samson, Rozwój idei ochrony konsumenta po 1962 r. Konsument w ujęciu prawnym i ekonomicznym, „Optimum. Studia Ekonomiczne” 2013, nr 3 (63), s. 163-174.

Ekonomia - Wroclaw Economic Review 24/4 (2018)

(C) for this edition by CNS 
Piotrowska M., Już 72 proc. Polaków używa suplementów diety. Jednak nie wszystkie produkty sa bezpieczne, https://polskatimes.pl/juz-72-proc-polakow-uzywa-suplementow-diety-jednak-nie-wszystkie-produkty-sa-bezpieczne/ar/12434864 (dostęp: 10.02.2018).

Pogorzelska E., Hamułka J., Analiza rynku suplementów diety z astaksantyna w Polsce, „Handel Wewnętrzny" 2013, nr 4.

Raport Suplementy diety/Pacjent/Rynek/Trendy/Regulacje, https://suplindex.com/wp-content/uploads/2017/10/RAPORT-Suplementy-diety-30.08.2017.pdf (data: 10.02.2018).

Rynek suplementów diety do 2021 roku będzie róst o 7 proc. rocznie. Obecnie jest wart 3,5 mld zt, https://biznes.newseria.pl/news/rynek-suplementow-diety,p609045232 (dostęp: 10.02.2018).

Rynek suplementów diety obecnie jest wart 3,5 mld zt, http://www.wirtualnemedia.pl/artykul/rynek-suplementow-diety-obecnie-jest-wart-3-5-mld-zl\# (dostęp: 10.02.2018).

Samson M., Rozwój idei ochrony konsumenta po 1962 r. Konsument w ujęciu prawnym i ekonomicznym, „Optimum. Studia Ekonomiczne” 2013, nr 3 (63).

Suplementy diety pod lupa. Kary i mandaty dla części producentów, https://tvn24bis.pl/z-kraju,74/ inspekcja-handlowa-skontrolowala-suplementy-diety,807118.html (dostęp: 4.01.2019).

Szadkowski S., Szokujacy raport NIK: Suplementy diety sa praktycznie poza kontrola, http://wgospodarce.pl/informacje/33445-szokujacy-raport-nik-suplementy-diety-sa-praktycznie-poza-kontrola-a-czesc-z-nich-moze-zawierac-narkotyki-i-drobnoustroje (dostęp: 10.03.2018).

UOKiK, Co warto wiedzieć o suplementach diety?, https://uokik.gov.pl/download.php?plik=17285 (dostęp: 12.02.2018).

Ustawa z dnia 25 sierpnia 2006 roku o bezpieczeństwie żywności i żywienia, Dz.U. Nr 171, poz. $1225 \mathrm{z}$ późn. zm.

Zajdel W., Wszechobecna reklama leków OTC oraz suplementów diety, http://www.rynekaptek. pl/wywiad/wszechobecna-reklama-lekow-otc-oraz-suplementow-diety, 13082.html (dostęp: 4.02.2018). 